\title{
...SICUT CERA IMPRIMITUR SIGILLO MNEMOTECHNICS IN THE SERMONS OF PEREGRINE OF OPOLE
}

\author{
Marcin Kietbus \\ marcin.kielbus@gmail.com \\ University of Silesia, Katowice \\ Poland
}

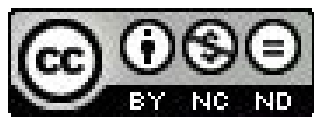

\begin{abstract}
This article demonstrates the functioning of ars memorativa in the works of Peregrine of Opole. Analyzing one of his sermons, we can see the presence of an ancient technique called imagines agentes.
\end{abstract}

Key words: Peregrine of Opole, sermon, ars praedicandi, exemplum, ars memorativa, imagines agentes.

At the end of the $12^{\text {th }}$ century a movement of itinerant preachers was reborn. The papacy was quite cautious of them, as they saw them as a threat to the church hierarchy and their doctrine. Rome raised concerns about both criticism of the wealth of the clergy and the level of knowledge of the dogmas. The remedy, according to the Papacy, was to be the approval of new orders, that would be officially authorized to preach. Absolute obedience and a great knowledge of the church's doctrine were demanded of these newly formed monastic structures. The increased level of preachers' education was followed by the development of evangelization and writing the first books on preaching. As a result of that, arranging sermons became a sophisticated art (ars praedicandi). A good sermon was supposed to be effective, which means that it should deepen the faith, but at the same time it should never leave the recipient unresponsive. This was backed up by the precision of construction of a sermon but also by the strength of arguments.

The earliest examples of this art in the Polish lands were de tempore and de sanctis written by Peregrine of Opole at the end of the $13^{\text {th }}$ century. Peregrine was in the Dominican order, the Order of Preachers (Ordo Praedicatorum). We shall focus on his work, based on one of his sermons (Peregrini de Opole 1997, p. 187-193).

According with the rules (Wolny 1961, p. 176-179), Peregrine always starts with the subject (thema) - a bible passage. In the sermon he used the first verse of the parable of the Gospel According to Saint Luke: "A man once gave a great banquet and invited many"3 (Lk 14,16). Then should follow some components of topic (divisio) that would have a metaphor assigned (sensus spiritualis). In this case Peregrine of Opole presents two main points (in his verbis possunt duo notary): the generosity of God, is presented by "a certain man" and perversity, by those who

Bible according to English Standard Version: http://www.biblegateway.com/versions/ English-Standard-Version-ESV-Bible/. 
did not accept the invitation for the supper. This is mentioned in the later part of the Gospel (Lk 14, 18-24), that the preacher will cite later on. We may also add the third point - defining the feast as the last judgment. It was extremely precious to present three elements. So the question is why didn't he write in his verbis possunt tria notari instead of duo notari? This helped him to show the importance of the host and guests, not the meeting itself. He built a hierarchy where people are more important than a place and circumstances.

These three elements are used as a core that, according to ars praedicandi rules, should be followed in the later part of the text (dilatatio) by the seriousness of authorities (auctores), examples (exempla) and other evidence.

But first, Peregrine introduces us to a scene of feast from Genesis (Ge 43,32). He shows Joseph who is making a feast for his brothers as Jesus on the day of the Final Judgment and Egyptians, who were moved away from the feast, as sinners. The introduction of Jesus to the sermon and showing him as the host is a sign of new and more individual christocentrism and this was getting more and more popular in the $13^{\text {th }}$ century thanks to the Order of Preachers, among others.

Then Peregrine develops the first point of the subject - generosity of the Host-Savior. He highlights the picture of the feast and this draws attention to a a society who was struggling against hunger at that time. The preacher shows a vision of the great feast (magna cena), with a countless numbers of dishes. The feast itself should bring a joy that is not to be compared with any other. This is backed up by some passages from the Book of Ezra, the Book and Numbers, the symbolism of fruits and an exemplum of a certain monk.

The considerable amount of space devoted to the feast might be surprising when comparing it to the hierarchy of values mentioned in divisio: the subjects should be more important than the place and circumstances. Peregrine explains that the praise of the feast is evidence of the generosity of the Host-Savior.

It is worth mentioning that generosity (largitas) starting from the Carolingian times, was an attribute of secular power and it was seen as a distinguishing virtue of great feudal lords as a contrast to the avaricious attitude of the peasants. Jesus is seen as the perfect lord and master, and this helps society to imagine what kind of character he is.

The development of the first point - generosity - closes the vision of Christ inviting four guests to the feast, which together with three scenes of the feast gives the number seven - the spiritual number. This is indication that the sermon itself was perfectly planned.

The second point of divisio shows the perversity of those who did not accept the invitation to the feast. Peregrine introduces us to the relevant section of the Gospel. Again, we have a symbolic number - three. Guests refuse to come to the feast, using the following cardinal sins as an excuse: pride (superbia) - in the Middle Ages known as the most important of all sins, greed (avaritia) and lust (luxuria).

Afterwards, Peregrine adds two expanded exempla, presenting different types of weakness. The first one refers to six characters symbolizing the six deadly sins and the other one refers to lust only. Three sins from the first parable, six sins from the first exemplum and one from the second one - this is ten in total - one of the favorite numbers in the Middle Ages (Lurker 1989; Forstner 2001). 
Below the second exemplum there is only a short phrase ending the sermon (unitio).

Two main points of dilatatio present two subjects from two parts of the sermon. The first part is devoted to God and it was based on the number seven. The second part shows ten views of sinners (collective entity), and the number ten may be read as a symbol of multiplicity, as rounding to tens, hundreds and thousands was the way multiplicity was presented.

But in this sermon more important than the feast itself seems to be the view of six sinners. First of all because this part is the most visible in the whole sermon but also because of its amazing content.

It must have been amazing for Peregrine as well, since it was directly proceeded by two literary tricks. Here is the first one: "We read that the Romans worshiped Saturn as the god, which they called »the fertile« or »satiating year «". They did so because that asserted fertile year for them" ${ }^{\prime 4}$ (Peregrini de Opole 1997, p. 190).

Peregrine wanted to explain the mythological origin of a character who will appear in the exemplum and to show its archaic provenance by using the phrase "we read that" (legitur, quod). The second trick was based on the appeal to the authority, in this case it was the strengthening the theme of a wise man: "a wise man says" (de isto scribit quidam sapiens).

Now follows the original story:

"Saturn arranged a great feast and invited all the creatures of this world to it. When the feast was already prepared, all invited animals came, with exception of six, which were invited but declined. The first was a pig, which had the following excuse: »If there are no pods and chaff to eat and dirty water to drink, I will not come«. The second was a crow, which replied: »If there are no corpses to peck, I will not come «. The third was an owl, which replied: »If there is no darkness, I will not come«. The fourth one was a frog, which replied: »If there is no mud to eat, I will not come«. The fifth was a fox, which replied: »If there are no creatures that I could cheat, I will not come«. The sixth one was a fly, which replied: »If there is no filth, which I could mess up myself, I will not come «"5 (Peregrini de Opole 1997, p. 190).

According to the preacher, Saturn is the Filius Dei, the Son of God. The pig (porcus) presents people who live in the sins of pride, immorality, greed and anger. The crow (corvus) pictures thieves, rogues and exploiters. The owl (noctua) presents slanderers and disturbers and their bad language (mala ligua) is the worst part of a body. Peregrine cites the famous concept of Aesop. He was sent by his master to the fair to buy the best and then the worst quality of meat and every

4 Legitur, quod Romani colebant pro deo Saturnum, qui dicitur fertilis sive satur annus. Hoc ideo fecerunt, ut eis annum fertilem administraret. All english translation by myself.

5 De isto scribit quidam sapiens, quod fecerit cenam magnam et ad illam omnia huius mundi animalia invitavit. Parata cena omnia, quæ invitata fuerant, venerunt, sed sex genera ex eis venire contempserunt. Primum fuit porcus qui se excusavit dicens: "Si non sunt in convivio siliquæe et furfures ad comedendum et ad bibendum aquæ immundx, non veniam". Secundum fuit corvus qui respondit: "Si non sunt ibi cadavera mortuorum ad comedendum, non veniam". Tertium fuit noctua quæ respondit: "Si non sunt ibi tenebræ, non veniam". Quartum fuit rana quæ respondit: "Si non est ibi terra ad comedendum, non veniam". Quintum fuit vulpes quæ respondit: "Si non sunt ibi creaturæ, quas decipere possum, non veniam". Sextum fuit bruchus qui respondit: "Si non est fimus, cui me involvere possum, non veniam". 
time he comes back with tongues. The frog (rana) is a symbol of greed, which involves sadness, worries, hunger, usury and constantly thinking about money. The fox (vulpes) presents witches and heretics that use "beautiful and sweet words deceives and deludes man like a fox, who praised the crow, to get the cheese" (Peregrini de Opole 1997, p. 192). The last one is a fly (bruchus). It is a symbol of an adulterer, who would rather lie under the fence than with his own wife, the preacher says: "Just makes the fly, which flies through the green meadow, avoids beautiful flowers, and drawn to the fetid filth [in foetido fimo]" (Peregrini de Opole 1997, p. 192).

Using exemplas in preaching wasn't anything unusual. They were often used by the Fathers of the Church, e.g. Tertulian (died in ca 220). He is known as a precursor of this technique in Christian literature (Panuś 2007, p. 144). It is also worth mentioning Gregory the Great and his Book of Pastoral Rule (Liber Regulae Pastoralis). The author orders the adaptation of the level of a sermon to the level of public, to leave the evidence of the rational for wise men. For ordinary people it is easier to understand examples (Grzegorz Wielki 1948, III, 6). Also the theorists artes praedicandi of the $13^{\text {th }}$ century advised the use examples in preaching ${ }^{6}$.

Exemplas were often treated as a help to understanding the difficult texts (Szostek 1997, p. 13). They were also seen as pleasurable and this was a referral to ancient rhetoric "to move and delight" docere - delectare. But let us remember that in ancient rhetoric a speech consisted of three parts (tria officia dicendi): docere - movere - delectare (Korolko 1990, p. 46-47). Movere was quite often omitted by Polish researchers. Jerzy Wolny is an exception (Wolny 1978, p. 247). A leading authority on the Middle Ages, St Augustine, in his book for preachers - De doctrina Christiana - writes: "If, however, the hearers require to be roused rather than instructed, in order that they may be diligent to do what they already know, and to bring their feelings into harmony with the truths they admit, greater vigour of speech is needed. Here entreaties and reproaches, exhortations and upbraidings, and all the other means of rousing the emotions, are necessary" (Augustine IV, 4).

Let us focus on these "all the other means of rousing the emotions [valent ad commovendos animos]" (Augustine IV, 4) and at animals that Peregrine mentioned in his text.

Animal symbolism in the Middle Ages was variable and determined by the context. E.g. they were always seen in a good light when they appeared on coins, but when they were mentioned in a sermon they could be treated in a different way and this is why a commentary was necessary. There are also some species of fauna that fell into disrepute - pig, crow, owl, frog, fox and fly (Kobielus 2002). Choosing them to present deadly sins seems to be very accurate. Moreover Peregrine not only combines an animal with a sin but he also emphasizes their negative qualities. This helped him to show the third part of ancient principles - movere. In fact, the objective of the sermons was to shake the conscience of the faithful (Augustine IV, 13). Augustine, however, warned against the danger of superficial change of mind under the influence of style based on emotions. He pointed out that when emotions subside nothing will remain in the mind of the listeners.

6 See typical ars praedicandi: Robert of Basevorn 2001, p. 114-215. 
The solution to the problem would be the art of memory (ars memorativa). As demonstrated by Frances Yates, this art was only apparently absent in the Middle Ages. In reality, the book Ad Herennium was known very well but it was called Second Rhetoric (or New Rhetoric) as it was mistakenly thought that Cicero was the author and the book was read together with First Rhetoric (or Old Rhetoric) (Yates 1999, p. 54). "The importance of this association for the understanding of the mediaeval form of the artificial memory is very great. For Tullius in his First Rhetoric gave much attention to the ethic and to the virtues as the »invention « or »things « with which the orator should deal in his speech. And Tullius in his Second Rhetoric gave rules as to how to the »invented « things were to be stored in the treasure-house of memory" (Yates 1999, p. 55).

For us, the most important of all rules is a theory images agentes - a method of combining text with images. This theory was mentioned in the $13^{\text {th }}$ century by Thomas Aquinas, among others. The main point of images agentes was to use associations of beauty and eyesore for easy memorization of spiritual concepts (Yates 1999, p. 74).

These conditions are well satisfied by animals in an exemplum used by Peregrine of Opole. Pig, crow, owl, frog, fox and fly are well known to the people of Europe. Moreover all these animals evoke emotions, so they serve as movere. This applies even to a pig, the only farm animal of this group, that could bring a material benefit. But in this case it seems that the Judaic tradition had a lot to do with a negative perception of a pig - in the Bible a pig is recognized as being impure. The recognition of animals helps to present more difficult abstract content. In this case, according to the second point - dilatatio, it helped to show the perversity of the people who rejected the invitation of Christ, the stigma of sin.

In Peregrine's sermon, the exemplum is not in conflict with moralisatio - on the contrary, the commentary reinforces the impression by adding certain more base elements:, eyes driven into the ground, dirt under a fence or smelly muck. This makes the sermon more clear, consistent and plain and Peregrine's education on the types of sin more easy to remember.

The above analysis of Peregrine's sermon proves the author's skill and his knowledge of the difficult art of preaching. The structure of the text shows that the content was carefully planned and the appropriate introduction of the feast scene indicates high skills of the author. In this context it looks as though the exempla of the animals invited to the feast was not only important as a function of relaxation (delectare). It could be a side effect, the main objective was to influence public imagination.

\section{BIBLIOGRAPHY}

Forstner D. (2001), Świat symboliki chrześcijańskiej. Leksykon, Pax, Warszawa.

Geremek B. (1978a), Exemplum i przekaz kultury, [in:] Geremek B. (ed.), Kultura elitarna a kultura masowa w Polsce późnego średniowiecza, Ossolineum, Wrocław.

Geremek B. (ed.) (1978b), Kultura elitarna a kultura masowa w Polsce późnego średniowiecza, Ossolineum, Wrocław.

Grzegorz Wielki [Gregory the Great] (1948), Księga reguty pasterskiej, Księgarnia Akademicka, Poznań. Kobielus S. (2002), Bestiarium chrześcijańskie. Zwierzęta w symbolice i interpretacji. Starożytność $i$ średniowiecze, Pax, Warszawa. 
Korolko M. (1990), Sztuka retoryki. Przewodnik encyklopedyczny, Wiedza Powszechna, Warszawa.

Lewański J. (ed.), Średniowiecze. Studia o kulturze, PWN, Warszawa.

Lurker M. (1989), Stownik obrazów i symboli biblijnych, Aletheia, Poznań.

Murphy J.J. (ed.) (2001), Three medieval rhetorical artes, University of California Press, Tempe.

Panuś K. (2007), Historia kaznodziejstwa, Salwator, Kraków.

Peregrini de Opole (1997), Sermones de tempore et de sanctis, Tatarzyński R. (ed.), Instytut Tomistyczny, Warszawa

Robert of Basevorn (2001), The Form of Preching, [in:] Murphy J.J. (ed.), Three medieval rhetorical artes, University of California Press, Tempe.

Szostek T. (1997), Exemplum w polskim średniowieczu, Wydawnictwo IBL, Warszawa.

Wolny J. (1961), Łaciński zbiór kazań Peregryna z Opola i ich zwiazek z tzw. "Kazaniami gnieźnieńskimi", [in:] Lewański J. (ed.), Średniowiecze. Studia o kulturze, PWN, Warszawa.

Wolny J. (1978), Exampla z kazań niedzielnych Peregryna z Opola, [in:] Geremek B. (ed.), Kultura elitarna a kultura masowa w Polsce późnego średniowiecza, Ossolineum, Wrocław.

Yates F. (1990), The art of memory, Routledge, London.

\section{NETOGRAPHY}

St. Augustine, On Christian Doctrine http:/ / www.intratext.com/IXT/ENG0137/, retrieved: 27.08.2012. Bible, http://www.biblegateway.com/versions/English-Standard-Version-ESV-Bible/, retrieved: 27.08.2012. 